\title{
Politics of Performance: a Study of Kandasamy’s Novel When I Hit
}

\section{You}

Subham Paul

Independent Researcher

Halisahar West Bengal, India

subhampaul1103@gmail.com

\begin{abstract}
"... [T] he category "woman" as well as the category "man" are political and economic categories not eternal ones" as commented by Monique Wittig. However, in any patriarchal society these categories are treated to be eternal through repeated naturalisation determining 'ideal' gender roles for both the genders. In Kandasamy's novel When I Hit You the 'young wife' started to imbibe and epitomise the role of an 'ideal wife' as determined by the patriarchal society. The novel emphasises on the performativity of the pre-assigned gender roles of the protagonist and the authoritative agencies of patriarchy determining her as "evil spirit" when faced with performative resistance. In this dialectics of performance and resistance the writer's words become the tool of resistance for the marginalised 'young wife' of Kandasamy's novel. Her criticism is not only against the construction of these gendered roles but also against their naturalisation and appropriation. The primary focus of this paper is thus to discuss the politics behind the gendered roles and the agenda of interpellation working behind the project of their naturalisation with a focus on the necessity of subversion of these roles for the protection of the individual self.
\end{abstract}

Keywords: Gender Roles, Naturalisation, Docile Body, Politics of Performance, Resistance. 
"Lights, camera, action. Rolling, rolling, role-playing"

(Kandasamy 17)

Playing the role of an 'ideal wife' is not anymore a choice for the 'young wife' in Kandasamy's novel When I Hit You, rather her life depends on her performance. The institution of marriage actually worked in the process of her entrapment in the hand of her 'husband'. The complexity in this problematic relationship not only lies in the naturalisation of the gendered roles but also in the appropriation of these roles by the husband with his violent 'disciplinary' methods. The space of three rooms and a veranda of the Primrose Villa actually worked as the "carceral system" where the husband, through his nature of surveillance, could watch over and control each and every movement of the wife (Sheridan 271). Meena Kandasamy's novel on one hand is the story of suffering of a young wife in her violent marital relationship and on the other is simultaneously depicting the story of a writer's fight for her own survival. The creation of the gender roles and the myth behind them along with their naturalisation has a particular agenda or propaganda behind it. The myths are actually being used for the purpose of appropriation of the gender roles and to retain the hierarchical power structure of the society. In order to understand properly the propaganda behind the creation and maintenance of the gender roles we need to breakdown the process in which they actually work. This paper will try to delineate the process in which the gender roles are shown to be working in Kandasamy's novel for the cause of subversion of women and will also try to decode the power-politics that is working as the basis for this process.

Simone de Beauvoir in the chapter entitled as "Myth and Reality" of her book The Second Sex has raised the question about the important role that "the myth of woman" (Parshley 260) plays in daily life. The myth of woman along with its specific characteristics plays a very significant role in the naturalisation of the superior/inferior binary opposition. The feminine characteristics being created and appropriated by patriarchy helps it to pose 
man as the 'self' against this 'other' named woman. It not only paves the way for her subversion but also negates her identity as an individual, a fellow human being - "To pose woman is to pose the absolute Other, without reciprocity, denying against all experience that she is a subject, a fellow human being" (Parshley 260). The protagonist being unable to cope with this marriage, which constantly demands from her to perform certain roles in certain ways, finds it easy to enact. She finds it easier to imagine her married life, in which she is entrapped, as a film. By considering herself as an actress she is now being able to play the "role as a perfect wife" which otherwise was not understandable for her as a fellow human being (Kandasamy 15). As a part of her performance even her choice of dress depends on the approval of the 'master', "Nothing loud, nothing eye-catching, nothing beautiful....like a woman whom no one wants to look at or, more accurately, whom no one even sees" (Kandasamy 16). After being able to control the appearance of his wife in the next level in this 'master-slave' relationship it was now time to take control of the social life of the wife too. Total control actually leads to total domination. First she is being forced to deactivate her Facebook account, which was her only professional link with the world as a writer, and then subsequently the attack came on her email id and phone number. Now after being completely shut down from the world and trapped in a particular place for months the application of the disciplinary methods finally started. His use of Marxist theoretical references for the purpose of justifying his own ideas and methods is also really interesting. The use of the theoretical references by the husband for the justification of his own logics and to hegemonise the wife itself explains the way how ISA actually works. The ironical part is that the same person who talks about the ideas of enslavement through corporate media, elite prostitution, sexual anarchy is himself trying to impose the disciplinary methods, on his wife, in order to retain his power and position as the master of the house and the marital relationship. What we consider as natural or physical is merely a mythical construction and there lies the politics of 
transformation, because "before being seen that way, they first had to be made that way" (Wittig 1908). Starting from torturing her psychologically to physical torture everything is applied by him in order to mould this body of this fellow human being into a 'perfect wife'. Patriarchy has naturalised the idea of 'perfect wife' in this way that the "docile" body of the female can be turned into a 'perfect wife' through the usage of proper disciplinary methods like applying the 'superior-inferior'/ 'master-slave' dialectics or through violence (Sheridan 136). The master has now made his grip so tight around her life that even the acts like using the internet or her writing activities now depend on his mercy. It is in the naturalisation of the division of the gender roles where lies the problem as Monique Wittig has stated "...by admitting that there is a "natural" division between women and men, we naturalize history, we assume that "men" and "women" have always existed and will always exist. Not only do we naturalize history, but also consequently we naturalise the social phenomena which express our oppression, making change impossible" (Wittig 1907).

The way the parents of this wife defend the activities of their son-in-law itself proves how these ideas, regarding the gender roles, have become an integral part of the society. We are now so adapted with these ideas that even the thought of questioning their logical existence never comes to our mind. They have become very much normal to us. When her mom is being informed by the daughter about the forceful restrictions upon her she reacted by explaining it as a natural characteristic of men: "Suspicion is in the nature of men; it is in the nature of love" (Kandasamy 56). Her father suggests her not to raise her voice or to talk back against the physical torture of her husband because he thinks that "Silence is a shield and it is also a weapon" (Kandasamy 157) and this is the perfect response against the violence of her husband. A female with the idea of becoming a writer, with the courage of questioning the ideas behind the society constructed roles is considered to be very dangerous for the society, as a demon. And the physical torture of the husband is just a way of casting 
the demon out of his 'possessed wife', because "even the kindest Tamil witch-doctors believe that the possessed woman must be whipped" (Kandasamy 154).

It is not be believed that the only reason behind the subversion and oppression of this wife in the hands of her husband is her economic dependence on her husband. The situation will not change magically by only fulfilling the criteria of becoming economically independent. In Anita Nair's Ladies Coupe when Akhila decided to buy a separate flat to live alone she is faced with the challenge of asking for the permission from her brothers, because after their father's death "They are the men of the family" (Nair 204). When being told about Akhila's plan her sister Padma naturally reacts in this way "Do you think that the brothers will consent to this? Do you think they'll let you live alone?" without realising the fact that Akhila is an adult woman who neither needs the permission nor the economical support of her brothers (Nair 204). Akhila's economical independence along with her sense of independence provide her the courage to finally decide to live her life on her own terms. Generally symbols or ideas are being defined or represented through the use of binary oppositions, thus the idea of the 'ideal woman' (who perfectly performs the society approved gender roles) is always being presented alongside the idea of the 'evil spirit' (possessed with the idea of freedom/ independence, who dares to question the society approved roles). The representation of women, as a class, through such binary opposite ideas actually helps patriarchy in the categorisation of women in two simple categories: one that perfectly plays the role as a 'daughter', 'sister', 'wife', 'mother' with the society-constructed perceptions attached to these roles and if anyone contradicts the definition provided for these roles she is then being treated as a threat to the society. And in order to protect the society from these 'evil spirits' it then becomes the 'duty' of patriarchal hierarchy to use proper 'disciplinary methods' so that they imbibe the role of the 'ideal woman'. The politics of myth formation lies so deep that even the idea of motherhood is being treated in different ways depending 
upon the situation. The same idea of motherhood which society defines as the 'most important duty of woman' is treated as a destructive notion for the society if someone wishes to become a mother without getting married. In order to expose this hypocrisy of society regarding marriage on one hand we have the young wife of Kandasamy's novel who is being pressurised for giving the 'good news' just only after the four months of the marriage and on the other hand we have the character of Leela Benare from Vijay Tendulkar's play Silence! The Court Is In Session whose character is being thoroughly scrutinised and criticised just because she wants to become a mother without being married to someone. The wife though does not want to bring a baby in this world since she feels there is no love. More so just because she is constantly being pressurised to get pregnant by her husband and even by her parents along with the whole society. They feel that a child will solve the problems between her and her husband as well as it is one of her most important duties as a wife to produce children. On the other hand Leela Benare's wish is being criticised by people like Sukhatme on the ground that "Motherhood without marriage has always being considered a very great sin by our religion and our traditions" and "[I]f it is encouraged, there will be no such thing as the institution of marriage left. Immortality will flourish" (Adarkar 100). In this patriarchal society a man feels himself to be so powerful that she can force a woman to become a mother against her own will and also can deny a woman to become a mother when he thinks it is correct to do so. Against Benare's wish Sukhatme responds "A woman bears the grave responsibility of building up the high values of society....Woman is not fit for independence" itself proves how the construction of the myth of woman is actually a process of denying her the basic rights as a fellow individual being (Adarkar 100). When she is constantly being compared with the notions related to the roles of an 'ideal woman' she is actually being forced to forget about her identity as an individual subjective self and pursue the notions connected with the gender roles. 
Gender roles and their performance along with their mythical construction is the space in which patriarchy operates with its power politics. In the process of exposition of this patriarchal politics and its subversion the destruction of the myth of woman is really necessary. As Monique Wittig has pointed out, "“Woman” is there to confuse us, to hide the reality "women". In order to be aware of being a class and to become a class we first have to kill the myth of "woman" including its most seductive aspects....But to become a class we do not have to suppress our individual selves" (Wittig 1910). In order to subvert her politics of performance the young wife not only decides to end this problematic marital relationship, and along with this the role of the 'perfect wife', but also chooses to give exposure to her writer self as part of her resistance. She finds it better to be the writer of her own story rather than being the subject of someone else's because the one thing that she has learnt from her experience is to "Don't let people remove you from your own story. Be ruthless..." (Kandasamy 09). 


\section{Works Cited}

Adarkar, Priya, translator. Silence! The Court is in Session. By Vijay Tendulkar, Oxford University Press, 2017, New Delhi.

Kandasamy, Meena. When I Hit You: or, A Portrait of the Writer as a Young Wife.

Juggernaut Books, 2017, New Delhi.

Nair, Anita. Ladies Coupe. Penguin Books, 2001, Gurgaon.

Parshley, H. M, translator. The Second Sex. By Simone De Beauvoir, Jonathan Cape, 1953, London.

Sheridan, Alan, translator. Discipline and Punish: The Birth of the Prison. By Michel Foucault, Vintage Books, 1977, New York.

Wittig, Monique. "One is Not Born a Woman". The Norton Anthology of Theory and Criticism, edited by Vincent B. Leitch, W. W. Norton \& Company, 2001, New York, pp. 1906-13. 